\title{
Kedudukan Hukum dan Fungsi Pemerintahan
}

\section{Oleh: Nurpaidah}

Berbicara mengenai kedudukan Hukum tidak terlepas dari Hukum Publik. Sehingga ${ }^{1}$ Di Indonesia saat ini, perhatian terhadap administrasi publik semakin lama semakin besar. Sering pemerintah Indonesia mengirim ke Amerika Serikat, Inggris, Brugge di Belgia, Australia, Filipina, dan beberapa negara lain, sejumlah pegawai negeri dan mahasiswa untuk meninjau dan mempelajari beberapa segi administrasi publik di negara-negara tersebut.

Administrasi publik mendapat perhatian begitu besar di Indonesia karena alasan berikut. Sistem pemerintahan yang oleh pemerintah Hindia-Belanda diwariskan kepada Indonesia, yang bersifat sangat bureaukratisch(dalam arti kata yang buruk) karena lebih memerhatikan segi-segi hukum persoalan daripada mencari penyelesaian persoalan secara praktis dan selalu mengutamakan kepentingan pemerintah pusat tidak lagi dapat menyalurkan dan memberi bentuk pada perkembangan ketatanegaraan dan politik yang baru sehingga harus diganti oleh suatu sistem baru. Namun, persoalan mengganti sistem pemerintahan yang telah ada dengan suatu sistem pemerintahan yang baru bukan suatu persoalan yang mudah.

Penggantian sistem pemerintahan yang telah ada berarti penggantian hukum tata negara positif yang menentukan kompetensi masing-masing jabatan negara, dan penggantian alam berpikir, pendidikan, dan pengalaman, yaitu kecakapan (keahlian) pegawai negeri yang telah ada.Dibandingkan dengan ilmu pemerintahan, administrasi publik lebih melihat usaha pemerintah sebagai suatu usaha perusahaan (bedrijf).

Oleh sebab itu, cara-cara penyelidikan yang digunakannya pun bersifat penyelidikan yang digunakan ilmu (ekonomi) perusahaan. Dibandingkan dengan bidang ilmu pemerintahan, bidang administrasi publik lebih luas, yaitu mempelajari persoalan-persoalan di luar bidang pemerintahan selama persoalan-persoalan tersebut berhubungan dengan pemerintahan.

Banyak pengarang yang menegaskan perbedaan antara hukum administrasi negara materiil dan hukum administrasi negara formal. Hukum ${ }^{2}$ administrasi negara materiil bertempat antara hukum privat dan hukum pidana. Ia menitikberatkan hubungan antara hukum administrasi negara formal dan bagian-bagian lain hukum formal. Ia menolak pendapat yang melihat "hukum administrasi negara sebagai suatu tambahan atau lanjutan hukum tata negara". Ia menegaskan bahwa hukum administrasi negara, yaitu:

1. menambah hukum privat;

\footnotetext{
${ }^{1}$ Dr. Sahya Anggara, M.Si., Hukum Administrasi Negara (Bandung: Cv Pustaka Setia, 2018), 32.

${ }^{2}$ Ibid.,34
} 
2. merupakan perkecualian terhadap hukum privat;

3. mengurangi hukum privat.

Hubungan Pemerintah dan Hubungan antar warga Negara sehingga muncul Pemerintahan dan Pemerintah.

${ }^{3}$ Istilah pemerintahan dan pemerintah sering disepadankan dengan istilah asing administratie, administration, bestuur, regering, dan government, dalam bahasa Indonesia digunakan juga istilah administrasi atau tata usaha negara. Beragamnya istilah yang disepadankan dengan istilah pemerintahan dan pemerintah menimbulkan berbagai macam pandangan para ahli mengenai pengertian dan makna pemerintahan dan pemerintah itu sendiri, yang mana pandangan para ahli tersebut belum mencapai titik kesepakatan, beragamnya pandangan para ahli tersebut memberikan warna akademis dalam kajian hukum tata negara maupun hukum administrasi negara. Misalnya, bestuur yang disepadankan dengan pelaksana pemerintahan, begitu juga dengan istilah government (pemerintahan) yang berasal dari bahasa latin "gobernaculum" yang memiliki arti " kemudi" fungsi "kemudi" ini seperti sebuah mobil, yang mana pemerintah yang menjalankan, namun secara umum istilah government lebih mudah dipahami sebagai "pemerintah" yaitu lembaga beserta aparaturnya yang mempunyai tanggung jawab untuk mengurus negara dan menjalankan kehendak rakyat

Berdasarkan literatur, Istilah pemerintahan dan pemerintah dapat dipahami dalam dua pengertian, yaitu: Pertama, pengertian dalam arti luas atau tertinggi, dalam arti luas dapat dilihat dari konsep Trias Politika dalam tiga cabang kekuasaan, kekuasaan membuat undangundang kekuasaan menjalankan undang-undang dan kekuasaan peradilan. Senada dengan konsep Trias Politika, Van Vollenhoven mengkaji pemerintahan dalam arti luas (bewinvoering, regeren) meliputi empat bidang kekuasaan, membuat peraturan perundang- undangan (regel geven), pemerintah/ pelaksana (bestuur), peradilan (rechtspraak) dan polisi (politie). Jadi pemerintahan/ pemerintah dalam arti luas merupakan segala bentuk kegiatan atau aktifitas penyelenggaraan negara yang dilakukan oleh organ -organ negara yang mempunyai otoritas atau kewenangan untuk menjalankan kekuasaan, pemerintahan dalam konteks ini mencakup kegiatan atau aktifitas penyelenggaraan negara yang dilakukan oleh eksekutif, legislatif, maupun yudikatif. Kedua, pengertian dalam sempit hanya mencakup badan atau kekuasaan eksekutif (pelaksana atau bestuur), tidak termasuk badan pembuat undang-undang dan badan peradilan. Menurut Laica Marzuki yang merujuk pada pandangan AM Donner, jika hendak

\footnotetext{
${ }^{3}$ Tanto Lailam, Pengantar Ilmu Hukum Administrasi Negara (Yogyakarta: Prudent Media, 2011), 100.
} 
memahami kekuasaan pemerintah, lupakan pembagian kekuasaan sebagaimana konsep trias politika, untuk kemudian membagi kekuasaan kenegaraan dalam dua bagian, sebagai penentu kebijakan dan perealisasi kebijakan (konteks ini yang disebut sebagai lapangan pekerjaan administrasi). ${ }^{4}$ Artinya bahwa pemerintahan dalam arti sempit memiliki batasan sebagai aktifitas maupun kegiatan yang diselenggarakan dalam kerangka fungsi maupun kegiatan yang diselenggarakan dalam kerangka fungsi eksekutif (bestuur) saja, lazimnya dilakukan oleh Presiden atau Perdana Menteri sampai pada jajaran yang paling rendah.

Pengertian pemerintah dibedakan yaitu sebagai organisasi dan fungsi, menurut Prajudi Atmosudirdjo pengertian pemerintah dapat dipandang sebagai aparatur (mechinary) pemerintah dan sebagai salah satu fungsi dan proses penyelenggaraan tugas pemerintahan. Sedangkan menurut Nata Saputra bahwa pengertian pemerintahan sebagai pelaksanaan tugas dan fungsi pemerintah,pemerintah berarti organ yang menjalankan pemerintahan, intinya kedua istilah tersebut dapat dibedakan, namun tidak dapat dipisahkan, mengingat kriteria pemerintah juga bergantung kepada cakupan fungsi pemerintahan. Berkaitan dengan konsep pemerintahan dan pemerintah, kita sering mendengar istilah yang sangat umum, seperti government, governance, dan public governance, uraian istilah ini tentunya akan menambah pemahaman mengenai konsep pemerintahan dan pemerintah, bahkan pengarahan atau administrasi yang berwenang atas kegiatan orang-orang dalam sebuah negara, negara bagian, kota dan sebagainya) atau lembaga/ badan yang menyelenggarakan pemerintahan negara, negara bagian, kota, dan sebagainya), Menurut Bappenas bahwa government secara umum lebih mudah dipahami sebagai "pemerintah" yaitu Lembaga beserta aparaturnya yang mempunyai tanggung jawab untuk mengurus negara dan menjalankan kehendak rakyat.

${ }^{5}$ Secara konstitusional, negara Indonesia menganut prinsip "negara hukum yang dinamis" atau welfare state sehingga tugas pemerintah Indonesia sangat luas. Pemerintah wajib berusaha memberikan perlindungan kepada masyarakat, baik dalam bidang politik maupun dalam sosialekonominya. Untuk itu, pemerintah memiliki kewenangan untuk ikut campur dalam berbagai kegiatan sosial untuk membangun kesejahteraan sosial, seperti melakukan pengaturan dalam kegiatan-kegiatan masyarakat dengan memberi izin, lisensi, dispensasi, dan lain-lain atau mencabut hak-hak warga negara tertentu karena diperlukan oleh umum.

Tugas pemerintah yang menyangkut pemerintah hukum administrasi negara pada saat ini ada lima, yaitu:

\footnotetext{
${ }^{4}$ Ibid., 101

${ }^{5}$ Dr. Sahya Anggara, M.Si., Hukum Administrasi Negara (Bandung: Cv Pustaka Setia, 2018), 19-20.
} 
1. Pemerintah hukum administrasi negara terdiri atas pengaturan, pembinaan masyarakat negara, kepolisian, dan peradilan,

2. Tata usaha negara, yang dilakukan melalui pengembangan dari pada birokrasi negara

3. Pengurusan rumah tangga negara, yang dilakukan melalui pengembangan dinasdinas pengurusan serta badan-badan usaha negara dan daerah

4. Pembangunan nasional, yang dilakukan dengan Bappenas serta Pelita-pelita

5. Penyelamatan dan pelestarian lingkungan.

Dengan demikian, administrasi negara dalam membantu menyelenggarakan kehendak dan keputusan-keputusan pemerintah dalam rangka tugas-tugas tersebut terdiri atas:

a. Administrasi pemerintah hukum administrasi negara

b. Administrasi ketatausahaan negara

c. Administrasi kerumahtanggaan negara

d. Administrasi pembangunan

e. Administrasi lingkungan. Administrasi negara tersebut dijalankan oleh para pejabat pemerintah yang merangkap sebagai pejabat administrasi (negara) dengan pejabat-pejabat pemerintah hukum administrasi negara, pejabat-pejabat administrasi. Para pejabat pemerintah ketika berkedudukan dan menjalankan fungsinya sebagai pejabat administrasi, dengan memimpin penyelenggaraan keputusan-keputusan pemerintah (yang bersifat politik) secara operasional kasualindividual mempergunakan wibawa dan wewenang administrasi yang bersifat teknis-penyelenggaraan (organisasi informasi)

Selain dari itu adapun Fungsi-Fungsi Pemerintahan

1. Fungsi Pengaturan

${ }^{6}$ Fungsi pengaturan adalah suatu tugas perundangan untuk mendapatkan/ memperoleh seluruh hasil legislatif dalam arti materiel. Dengan demikian, hasil dari fungsi pengaturan ini bukanlah undang-undang dalam arti formal (yaitu yang dibuat oleh presiden dengan persetujuan DPR), tetapi undang-undang dalam arti materiel, yaitu setiap peraturan dan ketetapan yang dibuat oleh pemerintah mempunyai daya ikat terhadap semua atau sebagian penduduk wilayah dari suatu negara.

${ }^{6}$ Dr. Sahya Anggara, M.Si., Hukum Administrasi Negara (Bandung: Cv Pustaka Setia, 2018), 18. 
${ }^{7}$ Fungsi ini dilaksanakan pemerintah dengan membuat peraturan perundangundangan untuk mengatur hubungan manusia dalam masyarakat. Pemerintah adalah pihak yang mampu menerapkan peraturan agar kehidupan dapat berjalan secara baik dan dinamis. Seperti halnya fungsi pemerintah pusat, pemerintah daerah juga mempunyai fungsi pengaturan terhadap masyarakat yang ada di daerahnya. Perbedaannya, yang diatur oleh Pemerintah Daerah lebih khusus, yaitu urusan yang telah diserahkan kepada Daerah. Untuk mengatur urusan tersebut diperlukan Peraturan Daerah yang dibuat bersama antara DPRD dengan eksekutif.

2. Fungsi Pelayanan

Perbedaan pelaksanaan fungsi pelayanan yang dilakukan Pemerintah Pusat dan Pemerintah Daerah terletak pada kewenangan masing-masing. Kewenangan pemerintah pusat mencakup urusan Pertahanan Keamanan, Agama, Hubungan luar negeri, Moneter dan Peradilan. Secara umum pelayanan pemerintah mencakup pelayanan publik (Public service) dan pelayanan sipil (Civil service) yang menghargai kesetaraan.

3. Fungsi Pembangunan

Pemerintah harus berfungsi sebagai pemacu pembangunan di wilayahnya, dimana pembangunan ini mencakup segala aspek kehidupan tidak hanya fisik tapi juga mental spriritual. Pembangunan akan berkurang apabila keadaan masyarakat membaik, artinya masyarakat sejahtera. Jadi, fungsi pembangunan akan lebih dilakukan oleh pemerintah atau Negara berkembang dan terbelakang, sedangkan Negara maju akan melaksanakan fungsi ini seperlunya.

Itulah Kedudukan Hukum dan Fungsi Pemerintahan di Indonesia.

${ }^{7}$ https://pemerintah.net/fungsi 